\title{
Front Matter: Volume 7329
}

, "Front Matter: Volume 7329," Proc. SPIE 7329, Three-Dimensional Imaging, Visualization, and Display 2009, 732901 (20 May 2009); doi: 10.1117/12.833837

SPIE Event: SPIE Defense, Security, and Sensing, 2009, Orlando, Florida, United SPIE. States 


\title{
PROCEEDINGS OF SPIE
}

\section{Three-Dimensional Imaging, Visualization, and Display 2009}

\author{
Bahram Javidi \\ Jung-Young Son \\ Manuel Martinez-Corral \\ Fumio Okano \\ Wolfgang Osten \\ Editors \\ 15-16 April 2009 \\ Orlando, Florida, United States \\ Sponsored and Published by \\ SPIE
}


The papers included in this volume were part of the technical conference cited on the cover and title page. Papers were selected and subject to review by the editors and conference program committee. Some conference presentations may not be available for publication. The papers published in these proceedings reflect the work and thoughts of the authors and are published herein as submitted. The publisher is not responsible for the validity of the information or for any outcomes resulting from reliance thereon.

Please use the following format to cite material from this book:

Author(s), "Title of Paper," in Three-Dimensional Imaging, Visualization, and Display 2009, edited by Bahram Javidi, Jung-Young Son, Manuel Martinez-Corral, Fumio Okano, Wolfgang Osten, Proceedings of SPIE Vol. 7329 (SPIE, Bellingham, WA, 2009) Article CID Number.

ISSN 0277-786X

ISBN 9780819475954

Published by

SPIE

P.O. Box 10, Bellingham, Washington 98227-0010 USA

Telephone +1 3606763290 (Pacific Time) · Fax +1 3606471445

SPIE.org

Copyright (C) 2009, Society of Photo-Optical Instrumentation Engineers

Copying of material in this book for internal or personal use, or for the internal or personal use of specific clients, beyond the fair use provisions granted by the U.S. Copyright Law is authorized by SPIE subject to payment of copying fees. The Transactional Reporting Service base fee for this volume is $\$ 18.00$ per article (or portion thereof), which should be paid directly to the Copyright Clearance Center (CCC), 222 Rosewood Drive, Danvers, MA 01923. Payment may also be made electronically through CCC Online at copyright.com. Other copying for republication, resale, advertising or promotion, or any form of systematic or multiple reproduction of any material in this book is prohibited except with permission in writing from the publisher. The CCC fee code is 0277-786X/09/ $\$ 18.00$.

Printed in the United States of America.

Publication of record for individual papers is online in the SPIE Digital Library.

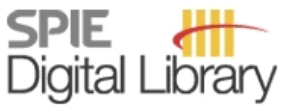

SPIEDigitalLibrary.org

Paper Numbering: Proceedings of SPIE follow an e-First publication model, with papers published first online and then in print and on CD-ROM. Papers are published as they are submitted and meet publication criteria. A unique, consistent, permanent citation identifier (CID) number is assigned to each article at the time of the first publication. Utilization of CIDs allows articles to be fully citable as soon they are published online, and connects the same identifier to all online, print, and electronic versions of the publication. SPIE uses a six-digit CID article numbering system in which:

- The first four digits correspond to the SPIE volume number.

- The last two digits indicate publication order within the volume using a Base 36 numbering system employing both numerals and letters. These two-number sets start with 00, 01, 02, 03, 04, $05,06,07,08,09,0 A, 0 B \ldots 0 Z$, followed by 10-1Z, 20-2Z, etc.

The CID number appears on each page of the manuscript. The complete citation is used on the first page, and an abbreviated version on subsequent pages. Numbers in the index correspond to the last two digits of the six-digit CID number. 


\section{Contents}

vii Conference Committee

\section{SESSION 1 3D AND RELATED TECHNOLOGIES}

732902 Research on ultra-realistic communications (Invited Paper) [7329-01]

K. Enami, National Institute of Information and Communications Technology (Japan)

732903 Challenge of 3D LCD displays (Invited Paper) [7329-02]

R.-Y. Tsai, C.-H. Tsai, K. Lee, C.-L. Wu, L.-C. D. Lin, K.-C. Huang, W.-L. Hsu, C.-S. Wu, C.-F. Lu,

J.-C. Yang, Y.-C. Chen, Industrial Technology Research Institute (Taiwan)

$732904 \quad$ Nonperiodic spatial masking for geometrical super resolved imaging (Invited Paper) [7329-03]

A. Borkowski, Z. Zalevsky, Bar-llan Univ. (Israel); B. Javidi, Univ. of Connecticut (United States)

732905 Advances in 3D asphere testing and reconstruction (Invited Paper) [7329-04]

C. Pruss, E. Garbusi, W. Osten, Univ. Stuttgart (Germany)

\section{SESSION 2 INTEGRAL PHOTOGRAPHY I}

732906 Extension of the depth of field in integral imaging: an overview (Invited Paper) [7329-05]

S. Bagheri, IBM Thomas J. Watson Research Ctr. (United States); B. Javidi, Univ. of Connecticut (United States)

732907 Analysis of incident light rays into a pupil in integral imaging (Invited Paper) [7329-06] F. Okano, J. Arai, M. Kawakita, Japan Broadcasting Corp. (Japan)

732908 Computational reconstruction of three dimensional integral imaging by rearrangement of elemental image pixels [7329-07]

M. Cho, B. Javidi, Univ. of Connecticut (United States)

732909 In-water 3D integral imaging [7329-08]

R. Schulein, B. Javidi, Univ. of Connecticut (United States) 
7329 OA Processing of optically captured digital holograms for three-dimensional display (Invited Paper) [7329-09]

T. J. Naughton, Univ. of Oulu (Finland) and National Univ. of Ireland, Maynooth (Ireland);

T. Kreis, BIAS-Bremer Institut Für Angewandte Strahltechnik GmbH (Germany); L. Onural,

Bilkent Univ. (Turkey); P. Ferraro, Istituto Nazionale di Ottica Applicata, CNR (Italy);

C. Depeursinge, École Polytechnique Fédérale de Lausanne (Switzerland); Y. Emery, Lyncée

Tec SA (Switzerland); B. M. Hennelly, National Univ. of Ireland, Maynooth (Ireland);

M. Kujawiñska, Warsaw Univ. of Technology (Poland)

7329 OB Comparison between a new holographically generated complex filter and the binary phase filter for depth-of-field extension [7329-10]

F. Diaz, Thales Research \& Technology (France) and Lab. Charles Fabry de l'Institut d'Optique, CNRS (France); F. Goudail, Lab. Charles Fabry de I'Institut d'Optique, CNRS (France); B. Loiseaux, J.-P. Huignard, Thales Research \& Technology (France)

7329 OC Visual perception of digital holograms on autostereoscopic displays [7329-11] T. M. Lehtimäki, K. Sääskilahti, R. Näsänen, Univ. of Oulu (Finland); T. J. Naughton, National Univ. of Ireland, Maynooth (Ireland) and Univ. of Oulu (Finland)

7329 OD Hologram generation from orthographic view images of three-dimensional object and its optimization [7329-12]

J.-H. Park, N. Chen, G. Baasantseren, M.-Y. Shin, N. Kim, Chungbuk National Univ. (Korea, Republic of)

\section{SESSION 4 HOLOGRAPHIC 3D IMAGE II}

$7329 \mathrm{OE}$ Three-dimensional visualization and recognition of biological micro-organisms by use of partially temporal incoherent light in-line digital holographic microscopy [7329-13]

I. Moon, Chosun Univ. (Korea, Republic of); B. Javidi, Univ. of Connecticut (United States)

7329 OF Study on elimination of twin image in a combined dual-type digital hologram microscope system [7329-14]

M. Kim, S. Hong, K. Roh, K. Soh, Seoul National Univ. (Korea, Republic of); S. Shin, Alpha of Professional Person \& Technology, Inc. (Korea, Republic of); J.-Y. Son, Daegu Univ. (Korea, Republic of); J. Kim, Seoul National Univ. (Korea, Republic of)

7329 OG New alignment liquid crystal techniques for operation at harsh ambient conditions and high intensity light [7329-15]

Z. Celinski, L. Reisman, I. Harward, A. Glushchenko, Univ. of Colorado at Colorado Springs (United States)

$7329 \mathrm{OH} \quad$ Harmonic holography for three-dimensional cellular imaging (Keynote Paper) [7329-16] C.--L. Hsieh, Ecole Polytechnique Fédérale de Lausanne (Switzerland) and California Institute of Technology (United States); R. Grange, Ecole Polytechnique Fédérale de Lausanne (Switzerland); Y. Pu, D. Psaltis, Ecole Polytechnique Fédérale de Lausanne (Switzerland) and California Institute of Technology (United States) 
7329 ol Processing of three-dimensional flash lidar terrain images generated from an airborne platform (Invited Paper) [7329-17]

A. Bulyshev, Analytical Mechanics Associates, Inc. (United States); D. Pierrottet, Coherent Applications, Inc. (United States); F. Amzajerdian, NASA Langley Research Ctr. (United States); G. Busch, Coherent Applications, Inc. (United States); M. Vanek, R. Reisse, NASA Langley Research Ctr. (United States)

7329 0J Improved design of quantized phase-only masks for patterns projection [7329-18]

H. Duadi, Z. Zalevsky, Bar-Ilan Univ. (Israel)

7329 OK Design and implementation of mobile 3D DMB receiver [7329-19]

B. Lee, K. Yun, H. Lee, G. Lee, N. Hur, Electronics and Telecommunications Research Institute (Korea, Republic of)

\section{SESSION 6 3D VISUALIZATION II}

7329 OL Stereo images in millimeter-wave regime (Invited Paper) [7329-20]

J.-Y. Son, V. P. Guschin, S.-W. Yeom, S.-H. Kim, H. Lee, Daegu Univ. (Korea, Republic of)

7329 OM Holographic codes and object authentication (Invited Paper) [7329-21]

T. Fournel, Lab. Hubert Curien, CNRS, Univ. Jean Monnet Saint-Etienne (France)

7329 ON Optical fabrication of 3D scattering medium for secure optical memory card (Invited Paper) [7329-22]

O. Matoba, Y. Kitamura, K. Nitta, Kobe Univ. (Japan); W. Watanabe, National Institute of Advanced Industrial Science and Technology (Japan)

732900 Quality estimation for visual image in autostereoscopic 3D display [7329-23]

V. Saveljev, Hanyang Univ. (Korea, Republic of); J.-Y. Son, Daegu Univ. (Korea, Republic of); S.-B. Woo, Hanyang Univ. (Korea, Republic of); M.-C. Park, Korea Institute of Science and Technology (Korea, Republic of); D.-S. Lee, Daegu Univ. (Korea, Republic of); K.-D. Kwack, Hanyang Univ. (Korea, Republic of)

\section{SESSION 7 INTEGRAL PHOTOGRAPHY II}

7329 OP Progress in 3D imaging and display by integral imaging (Invited Paper) [7329-24]

R. Martínez-Cuenca, G. Saavedra, M. Martínez-Corral, A. Pons, Univ. de València (Spain);

B. Javidi, Univ. of Connecticut (United States)

7329 OR Three-dimensional visualization of scattered events by use of coherent integral imaging (Invited Paper) [7329-26]

I. Moon, Chosun Univ. (Korea, Republic of); B. Javidi, Univ. of Connecticut (United States)

7329 OS Three-dimensional image correlator using optically reconstructed integral plane images [7329-27]

Y.-R. Piao, S.-P. Hong, Kwangwoon Univ. (Korea, Republic of); D.-H. Shin, Dongseo Univ. (Korea, Republic of); E.-S. Kim, Kwangwoon Univ. (Korea, Republic of) 
7329 OT Free viewpoint TV and its international standardization (Invited Paper) [7329-28]

M. Tanimoto, Nagoya Univ. (Japan)

7329 OU Time-sequential autostereoscopic OLED display with segmented scanning parallax barrier (Invited Paper) [7329-29]

D.-S. Kim, S. Shestak, K.-H. Cha, S.-M. Park, S.-D. Hwang, Samsung Electronics Co., Ltd. (Korea, Republic of)

7329 OW Perceptive visual attention model based on depth information for free viewpoint video rendering [7329-32]

M.-C. Park, Korea Institute of Science and Technology (Korea, Republic of); J.-Y. Son, Daegu Univ. (Korea, Republic of)

\section{POSTER SESSION}

7329 OX Research of 3D visualization for landform and feature by VTK [7329-33]

R. Shi, S. Lu, L. Zhu, Beijing Univ. of Civil Engineering and Architecture (China)

7329 OY Efficient generation of holographic video of 3D objects by use of redundancy of image and look-up table methods [7329-34]

S.-C. Kim, Kwangwoon Univ. (Korea, Republic of); J.-E. Kang, Agency for Defense

Development (Korea, Republic of); E.-S. Kim, Kwangwoon Univ. (Korea, Republic of) 


\section{Conference Committee}

Symposium Chair

Ray O. Johnson, Lockheed Martin Corporation (United States)

Symposium Cochair

Michael T. Eismann, Air Force Research Laboratory (United States)

Conference Chairs

Bahram Javidi, University of Connecticut (United States)

Jung-Young Son, Daegu University (Korea, Republic of)

Conference Cochairs

Manuel Martinez-Corral, Universitat de València (Spain)

Fumio Okano, Ultra-Realistic Communications Forum (Japan)

Wolfgang Osten, Universität Stuttgart (Germany)

Program Committee

Saeed Bagheri, IBM Corporation (United States)

Frank Dubois, Université Libre de Bruxelles (Belgium)

Pietro Ferraro, Istituto Nazionale di Ottica Applicata (Italy)

Toshiaki Fujii, Tokyo Institute of Technology (Japan)

William E. Higgins, The Pennsylvania State University (United States)

Osamu Matoba, Kobe University (Japan)

Thomas J. Naughton, National University of Ireland, Maynooth (Ireland)

Takanori Nomura, Wakayama University (Japan)

Adrian Stern, Ben-Gurion University of the Negev (Israel)

Wa James Tam, Communications Research Center Canada (Canada)

Edward A. Watson, Air Force Research Laboratory (United States)

S. Yeom, Daegu University (South Korea)

Session Chairs

$13 \mathrm{D}$ and Related Technologies

Bahram Javidi, University of Connecticut (United States)

Fumio Okano, Ultra-Realistic Communications Forum (Japan)

2 Integral Photography I

Manuel Martinez-Corral, Universitat de València (Spain)

Saeed Bagheri, IBM Corporation (United States) 
3 Holographic 3D Image I

Thomas J. Naughton, National University of Ireland, Maynooth (Ireland)

$4 \quad$ Holographic 3D Image II

Thomas J. Naughton, National University of Ireland, Maynooth (Ireland)

Jung-Young Son, Daegu University (Korea, Republic of)

$53 \mathrm{D}$ Visualization I

Jung-Young Son, Daegu University (Korea, Republic of)

Zeev Zalevsky, Bar-llan University (Israel)

63 D Visualization II

Thierry Fournel, Université Jean Monnet Saint-Etienne (France)

Osamu Matoba, Kobe University (Japan)

7 Integral Photography II

Fumio Okano, Ultra-Realistic Communications Forum (Japan)

Osamu Matoba, Kobe University (Japan)

$8 \quad 3 D$ Displays and Image Processing

Rung-Ywan Tsai, Industrial Technology Research Institute (Taiwan)

Masayuki Tanimoto, Nagoya University (Japan) 